\title{
Sugar reduction of skim chocolate milk and viability of alternative sweetening through lactose hydrolysis
}

\author{
X. E. Li, ${ }^{*}$ K. Lopetcharat, $†$ Y. Qiu, ${ }^{*}$ and M. A. Drake ${ }^{* 1}$ \\ *Department of Food, Bioprocessing and Nutrition Sciences, Southeast Dairy Foods Research Center, North Carolina State University, \\ Raleigh 27695 \\ †Nouveau Centric Co. Ltd., Bangkok 10250, Thailand
}

\section{ABSTRACT}

Milk consumption by Americans has not met the standards of the Dietary Guidelines for Americans. Chocolate milk can improve milk consumption, especially by children, due to its color and taste. However, the high sugar content of chocolate milk is a cause for concern about its healthfulness, resulting in its removal from some school lunch programs. It is important to reduce the sugar content of chocolate milk and still maintain acceptability among consumers. It is also important to investigate other natural alternatives to sweetening. The objectives of this study were to identify the different sweetness intensity perceptions of sucrose in water and various dairy matrices, to identify the acceptable reduction in sweet taste for chocolate milk for both young adults (19-35 yr) and children $(5-13 \mathrm{yr})$, and to determine if lactose hydrolysis is a viable alternative. Threshold and power function studies were used to determine the benchmark concentration of sucrose in chocolate milk. The acceptability of sugar reduction from the benchmark concentration for both young adults and children and the acceptability of lactose hydrolyzed chocolate milk $\left(4^{\circ} \mathrm{C}\right.$ for $\left.24 \mathrm{~h}\right)$ with added lactose for young adults were evaluated. Acceptability results demonstrated that sugar reduction in chocolate milk is possible for both young adults and children as long as it does not exceed a $30 \%$ reduction (from $205 \mathrm{mM}$ ). Lactose hydrolysis of added lactose was used to achieve the sweetness of sucrose in chocolate milk but required $>7.5 \%$ (wt/vol) added lactose, which contributed undesirable calories, indicating that lactose hydrolysis may be more suitable for other dairy beverages that require less added sugar. The findings of this study demonstrate consumer acceptance of reduced-sugar chocolate milk and a possible way to use lactose hydrolysis in dairy beverages.

Received June 15, 2014.

Accepted September 28, 2014.

${ }^{1}$ Corresponding author: maryanne_drake@ncsu.edu
Key words: chocolate milk, power function, sugar reduction, lactose hydrolysis

\section{INTRODUCTION}

The Dietary Guidelines for Americans recommend that adult Americans consume 3 cups $(710 \mathrm{~mL})$ per day of fat-free or low-fat milk or equivalent milk products (USDA-HHS, 2010). Studies have shown that flavored milk increases milk consumption among both adults and children (Anonymous, 2003; Murphy et al., 2008). Flavored milk provides essential nutrients similar to that of plain milk and other milk products (Murphy et al., 2008) and, because of its pleasurable taste, has gained popularity among children and adults (Kim et al., 2013). In 2011, sales in flavored milk and milk drinks reached $\$ 731$ million in the United States (International Dairy Foods Association, 2012). Chocolate is the most popular milk flavor for both children and adults (Boor, 2001; Thompson et al., 2004, 2007; NDC, 2010). Various studies have addressed the relationship between high sugar consumption and health concerns such as obesity (Berkey et al., 2004; Malik et al., 2006); therefore, despite the popularity of chocolate milk and the benefit of increasing milk consumption for children and adults, the high sugar content of chocolate milk has raised health concerns. The Los Angeles school system recently banned flavored milk as part of a child obesity prevention program (Hoag, 2011). However, Quann and Adams (2013) determined that eliminating flavored milk in elementary schools decreased overall milk consumption and, to replace the nutrient deficit from the milk consumption, additional foods with more fat and calories would be required. Therefore, the balance between increasing milk consumption while maintaining low sugar content is important.

Sugar reduction is usually achieved by replacing sugar with nonnutritive sweeteners. However, the disadvantages of these sweeteners are that they are often artificial, which are not label friendly, and often carry metallic or bitter taste and aftertastes (Schiffman et al., 1995). The naturally existing milk sugar lactose has a lower relative sweetness compared with its monosac- 
charide constituents glucose and galactose. Lactase is currently used by the dairy industry to produce lactose-free milk. As such, lactose hydrolysis of milk with added dried dairy ingredients such as lactose or whey permeate might be a label-friendly method to sweeten chocolate milk naturally. Lactose hydrolysis is usually conducted before pasteurization of raw milk or after pasteurization followed by heat treatment to deactivate the enzyme. Sterile lactase can also be added into UHT milk with aseptic packaging, where the lactose will be hydrolyzed during the first few days of storage. If an acceptable sweetness of chocolate milk could be achieved by hydrolyzing added lactose or a high-lactose dairy ingredient such as whey permeate, it would provide an alternative way of sweetening chocolate milk. To our knowledge, no published work has addressed this question.

Various studies have been conducted on the effect of sugar reduction on sensory perception of different foods and beverages but to our knowledge, no studies have described the dose-response relationship of sucrose in different dairy matrices, especially chocolate milk. It is important to understand sweetness perception of chocolate milk and what level of sugar reduction can be achieved without affecting consumer acceptance. The objectives of this study were to identify the sweetness intensity perception of sucrose in water and various dairy matrices, to identify the acceptable sweet taste reduction for chocolate milk for both young adults and children, and to determine if lactose hydrolysis is a viable alternative to sweeten chocolate milk.

\section{MATERIALS AND METHODS}

\section{Experimental Overview}

Two experiments (experiments 1 and 2) were conducted to achieve the objectives of this study. In experiment 1 , the acceptable sugar reduction of skim chocolate milk for both young adults and children was identified. Threshold and power function studies were conducted to determine a representative concentration of sucrose in skim chocolate milk comparable to commercial product. Based on the benchmark concentration, different percentages of sucrose reduction in chocolate milk were evaluated by both young adults and children. In experiment 2 , the objective was to determine if lactose hydrolysis was a viable alternative to sweeten skim chocolate milk. The lowest acceptable sweet level from experiment 1 for both young adults and children was chosen as the sweet taste target for lactose hydrolysis experiments. The acceptance of chocolate milk sweetened by lactose hydrolysis compared with sucrose-sweetened chocolate milk was then evaluated by young adults.

\section{Chocolate Milk Manufacture}

Chocolate milk base without added sugar used for bench-top studies for power function and lactose hydrolysis studies was manufactured by adding $10.19 \mathrm{~g}$ of cocoa powder (NC85, Benjamin P. Forbes Company, Broadview Heights, $\mathrm{OH}$ ) to $1 \mathrm{~L}$ of raw skim milk. The mixture was pasteurized at $69^{\circ} \mathrm{C}$ for $30 \mathrm{~min}$, and then immediately fed to a 2-stage homogenizer (Panda 2K, Niro Inc., Columbia, MD) at 2,000 kPa (first stage) and $4,000 \mathrm{kPa}$ (second stage). The milk was cooled and stored at $4^{\circ} \mathrm{C}$. Sucrose was then added at different concentrations in each experiment. Chocolate milk for consumer tests was manufactured by the North Carolina State University (NCSU) Dairy Education Unit (Raleigh, NC) using skim milk and the same cocoa powder concentrations (described in the Consumer Acceptance sections).

\section{Experiment 1: Sugar Reduction in Skim Chocolate Milk}

Threshold Determination. All sensory testing protocols were approved by the NCSU Institutional Review Board. The detection and recognition threshold of sucrose in water, skim milk, whole milk, and skim chocolate milk was determined using a 7-series ascending 3-alternative forced choice method (ASTM International, 1991; Plotto et al., 2004; Drake et al., 2011). Samples $(30 \mathrm{~mL})$ were presented in lidded 60 $\mathrm{mL}$ souffle cups with 3 -digit codes, and the series was presented in ascending concentration. The sweetness levels were presented with a dilution factor of $3(0.111$ to $81 \mathrm{~m} M$ sucrose in water, 0.333 to $243 \mathrm{~m} M$ sucrose in milks). In each series, samples were randomized. All samples were equilibrated to $20^{\circ} \mathrm{C}$ before testing.

Subjects $(\mathrm{n}=40)$ were instructed how to evaluate the samples before testing, and the sure/not sure modification detailed by Lawless et al. (2000) was used. Subjects were asked to remove the cup lid and taste each sample, and then to choose the 1 item of the 3 that they thought was different. Subjects were also asked if they recognized the difference. Subjects were asked to give certainty judgments (sure/not sure) for both difference and recognition. The individual bestestimated threshold was determined by calculating the geometric mean of the last concentration with an incorrect response and the first concentration with a correct response, with all subsequent responses correct. If the subject indicated a "not sure" response for the correct choice, a factor of 1.41 was multiplied to adjust for the possibility of a chance correct response (Lawless et al., 2000; Leksrisompong et al., 2010). Group thresholds 
were determined by taking the geometric mean of the individual BET values.

Power Function of Sweetness in Different Media. Twelve panelists (9 females, 3 males, aged 21-55 yr) were used for generating power functions of sucrose in water, skim milk, and skim chocolate milk. Each panelist had some previous experience with descriptive analysis ( $\sim 25-50 \mathrm{~h}$ of training), and $5 \mathrm{~h}$ of additional training on sweet taste identification and magnitude estimation scaling was conducted. The starting sucrose concentrations in each food matrix were based on the recognition threshold of sucrose. Magnitude estimation scaling (Meilgaard et al., 1999) was used to create the power functions. For magnitude estimation, subjects were instructed to taste a reference sample $(100 \mathrm{mM}$ of sucrose in water) each time they evaluated solutions. This reference was assigned a value of 100 in sweet taste intensity. Nine concentrations for sucrose in water (12.87 to $218.79 \mathrm{mM}$ ) and skim milk (15 to $255 \mathrm{mM}$ ) were chosen, and 7 sucrose concentrations for skim chocolate milk (20 to $260 \mathrm{mM}$ ) were chosen. Each panelist evaluated each product in triplicate in separate sessions.

Acceptance of Sugar Reduction in Chocolate Milk by Young Adults. Chocolate milks with sweetness levels $205 \mathrm{mM}$ (current commercial sucrose concentration equivalent), $142.2 \mathrm{~m} M, 86.6 \mathrm{~m} M, 52.7 \mathrm{~m} M, 32.1$ $\mathrm{m} M$, and $17.14 \mathrm{~m} M$ (recognition threshold of sweetness in skim chocolate milk), which represented 30.6, 57.8, $74.3,84.3$, and $91.5 \%$ sucrose reductions from $205 \mathrm{~m} M$, were evaluated by consumers. The concentration levels were chosen from the results of power functions. Sucrose concentrations of 17.14 and $205 \mathrm{~m} M$ in chocolate milk were manufactured by the NCSU Dairy Education Unit. Raw milk (156 kg) was mixed with cocoa powder $(1.54 \mathrm{~kg})$ and sucrose $(0.89 \mathrm{~kg}$ for $17.14 \mathrm{mM}$ and 10.63 $\mathrm{kg}$ for $205 \mathrm{mM})$. The mixture was homogenized $(2,758$ $\mathrm{kPa}$ first stage and $3,447 \mathrm{kPa}$ second stage), pasteurized at $79.4^{\circ} \mathrm{C}$ for $20 \mathrm{~s}$, and then cooled to $4^{\circ} \mathrm{C}$. Other sucrose concentrations were prepared by mixing these 2 concentrations.

Consumers were recruited using an online screener using SSI Web (version 8.1.2, Sawtooth Software, Orem, UT) and were from the consumer database of more than 5,000 people maintained by the NCSU Sensory Service Center, with the target number of consumers being 145 . The recruitment criteria were $50 \%$ male, $50 \%$ female, ages 19 to $35 \mathrm{yr}$, and self-reported consumers of low-fat or skim chocolate milk at least 2 to 3 times per month. Samples were presented monadically, with the order of presentation completely randomized to prevent order of presentation effects. Chocolate milk with $86.6 \mathrm{mM}$ sucrose was chosen arbitrarily as an extra sample tested in addition to the 6 other sucrose concentrations for statistical purposes. Sixty milliliters of chocolate milk was poured into 3-digit coded, 177.4$\mathrm{mL}$ clear plastic tumblers (Waddington North America Inc., Chelmsford, MA) for consumer evaluation.

Consumers first answered demographic questions and were then presented with a chocolate milk, one at a time, and evaluated each milk based on appearance and taste. Consumers were required to have a 1-min rest with water/cracker rinse between milks. For each product, liking based upon appearance was evaluated first. After consumers consumed the chocolate milk, they evaluated samples for overall liking, flavor liking, sweetness liking, and just about right (JAR), cocoa flavor liking and JAR, thickness liking and JAR, and purchase intent. The liking scale was a 9-point scale where 1 = dislike extremely and $9=$ like extremely. The JAR scale was a 5 -point scale where 1 or $2=$ too little, $3=$ just about right, and 4 or $5=$ too much. Purchase intent was scored on a 5-point scale where 1 or $2=$ would not buy, $3=$ maybe/maybe not, 4 or 5 = would buy. Data collection was completed using Compusense Five (version 5.2, Compusense, Guelph, ON, Canada). All participants were compensated with a $\$ 10$ gift card to a local shopping store.

Acceptance of Sugar Reduction in Chocolate Milk by Children. Parents of children $(\mathrm{n}=50$ for $5-7 \mathrm{yr}, \mathrm{n}=50$ for $8-10 \mathrm{yr}, \mathrm{n}=50$ for $11-13 \mathrm{yr}$ ) were recruited from the same NCSU database, with the target number of consumers being 150 children. The recruitment criteria were children that drink chocolate milk at least 2 to 3 times per month. Parents and legal guardians of children in the target age range were prescreened using a screener created in SSI Web and launched into the database. In order for the children to participate in the test, their parents or legal guardians were required to read and sign a consent form that explained the purpose and the logistics of the study. An ingredients and allergens list for the chocolate milk was also provided and the test protocol was approved by the NCSU Institutional Review Board (NCSU IRB 1569-10-7).

Skim chocolate milks with sucrose concentrations at $86.6,126,140.6,162$, and $205 \mathrm{mM}$, which represented $57.8,38.5,31.4,21.0$, and $0 \%$ sucrose reductions from a current commercial sucrose concentration $(205 \mathrm{mM})$ were tested. The concentrations were chosen from the young adults' acceptance test and manufactured as previously described. Chocolate milks were presented monadically at $4^{\circ} \mathrm{C}$ with order of presentation completely randomized to prevent order of presentation effects. Three milks were evaluated by 5 - to 7 -yr-old children (86.6, 140.6, and $205 \mathrm{mM}$ ), and all 5 milks were evaluated by 8 - to 13 -yr-old children. Chocolate milk $(60 \mathrm{~mL})$ was poured into 3 -digit coded, 177.4-mL 
clear plastic tumblers. The children were presented with a chocolate milk, one at a time, and evaluated samples based on taste. For each product, after the children consumed the chocolate milk, 5- to 7-yr-old children evaluated milks for overall liking; 8- to 10-yrold children evaluated overall liking, sweetness, and chocolate flavor liking; and 11- to 13-yr-old children evaluated overall liking, sweetness liking and JAR, and chocolate flavor liking and JAR. The liking scale used was a 7 -point "smiley face" scale where $1=$ super bad and $7=$ super good (Kroll, 1990; Guinard, 2000). The JAR scale was a 3 -point smiley face scale where $1=$ too little, $2=$ just about right, and $3=$ too much.

For 5- to 7-yr-old children, paper ballots were used. One moderator was assigned to each child. Before evaluating milks, the moderator obtained the child's favorite and least favorite food information from the parent and practiced the scale with the child after reading the scale aloud to the child. If the child successfully identified their favorite food with a high score and their least favorite food with a low score, the moderator then proceeded with the child to evaluate chocolate milks. A practice (warm-up) has been suggested to improve a child's performance in sensory testing (Popper and Kroll, 2005). After the children tasted the samples, they then used a pen to circle or point at the face that represented how much they liked it.

Children 8 to 13 yr of age evaluated the milks using a computer with the smiley face scale, and assistance was provided if needed. After evaluating all milks, children were directed to pick which one was their favorite. Parents were instructed to help with demographic questions to indicate the child's sex, age, and chocolate milk consumption frequency at the end. Data collection was completed using Compusense Five (version 5.2, Compusense). All participants were compensated with a $\$ 25$ gift card to a local shopping store.

\section{Experiment 2: Alternative Sweetening by Lactose Hydrolysis}

Lactose Hydrolysis. Four commercially available enzymes containing $\beta$-galactosidase were obtained from 4 distributors. The enzymes included Ha-Lactase (HL; Chr. Hansen Inc., New Berlin, WI), GODO-YNL2 Yeast Neutral Lactase (GL; Danisco A/S, Copenhagen, Denmark), Lactozyme lactase (LL; Sigma-Aldrich, St. Louis, MO), and Maxilact (ML; DSM Food Specialties, Heerlen, the Netherlands). All the enzymes were derived from the dairy yeast Kluyveromyces. Raw whole milk, pasteurized whole milk, pasteurized skim milk, chocolate milk base, and 5\% (wt/wt) and $10 \%$ (wt/wt) lactose solutions in phosphate buffer prepared from 2 different manufacturers were tested with all 4 enzymes at different concentration levels $(0.1 \% \mathrm{wt} / \mathrm{vol}$ for milks and $5 \% \mathrm{wt} / \mathrm{wt}$ solutions, $0.1 \% \mathrm{wt} / \mathrm{vol}$ and $0.2 \% \mathrm{wt} / \mathrm{vol}$ for $10 \% \mathrm{wt} / \mathrm{wt}$ solutions) at $4^{\circ} \mathrm{C}$ for 12 and $24 \mathrm{~h}$. Five percent $(5 \% \mathrm{wt} / \mathrm{wt})$ and $10 \%$ (wt/wt) solids rehydrated spray-dried permeate solutions prepared from 5 different suppliers, and a fresh liquid permeate produced in the pilot plant as described in Li et al. (2012) were also tested $(0.1 \% \mathrm{wt} / \mathrm{vol}$ for $5 \% \mathrm{wt} / \mathrm{wt}$ solutions, $0.1 \% \mathrm{wt} /$ vol and $0.2 \% \mathrm{wt} / \mathrm{vol}$ for liquid permeate and $10 \% \mathrm{wt} /$ wt solutions) analogously.

Percentages of lactose hydrolysis were determined through HPLC using the method adapted from Upreti et al. (2006). One hundred microliters of each milk or solution was extracted in $900 \mu \mathrm{L}$ of mobile phase $0.013 \mathrm{~N} \mathrm{H}_{2} \mathrm{SO}_{4}$ (2N, VWR International, West Chester, PA), vortexed, and centrifuged at $8,000 \times g$ for 5 min. The top layer was filtered using $0.45-\mu \mathrm{m}$ nylon syringe filters (VWR International). Prepared samples were then placed on the HPLC (Waters 1525 Binary Pump, Waters, Milford, MA). Twenty microliters of the sample was injected (Waters 2707 Autosampler) onto the column $\left(55^{\circ} \mathrm{C}, 0.5 \mathrm{~mL} / \mathrm{min}, 300 \times 7.8\right.$ ion exclusion, Bio-Rad Laboratories, Richmond, CA,). The injector temperature was at $4^{\circ} \mathrm{C}$ and a refractive index (RI) detector (Waters 2414 Refractive Index Detector, $30^{\circ} \mathrm{C}$ ) was used. A 12-point standard curve for lactose (SigmaAldrich) was constructed over the range of 0.5 to 15,000 $\mathrm{mg} / \mathrm{kg}$ in mobile phase. Lactose hydrolysis percentages were calculated based on the standard curve and dilution factors and comparison of hydrolyzed samples to unhydrolyzed control samples.

Descriptive Analysis of Hydrolyzed Chocolate Milk. The GL and HL enzymes were chosen from lactose hydrolysis results based on hydrolysis percentages. Bench-top processed skim chocolate milks (described previously) with $0,2,5,7.5$, or $10 \mathrm{~g}$ of added lactose (Hilmar 5000 Natural Lactose, Hilmar, CA) per $100 \mathrm{~mL}$ or spray-dried commercial powdered permeate $(82.77 \%$ lactose) with $0,2,5,7.5$, or $10 \mathrm{~g}$ of lactose per $100 \mathrm{~mL}$ were hydrolyzed at $4^{\circ} \mathrm{C}$ for $24 \mathrm{~h}$ by GL and HL lactases with the goal to match the lowest acceptable sweetness level found in consumer tests. After hydrolysis, chocolate milks were heat treated at $85^{\circ} \mathrm{C}$ for $30 \mathrm{~s}$, to deactivate the lactase, and cooled to $4^{\circ} \mathrm{C}$. Milks were subjected to HPLC analysis to confirm lactose hydrolysis percentages $(>90 \%)$. Before sensory evaluation, all milks were equilibrated to room temperature $\left(20^{\circ} \mathrm{C}\right)$. A trained descriptive sensory analysis panel $(n=8$, females 24 to $44 \mathrm{yr}$ of age, not the same panelists as for sweet taste power functions) evaluated milk flavor attributes (aroma, cooked milk and chocolate flavor) and basic tastes (sweet, salty, and bitter) using the Spectrum descriptive analysis method (Meilgaard et al., 1999; Drake and Civille, 2003). Each panelist had more 
than $150 \mathrm{~h}$ of experience with descriptive analysis of dairy products. Preliminary evaluations of commercial and experimental milks in blinded sessions confirmed that the panel and panelists were able to consistently differentiate $(P<0.05)$ products and attributes. Milks were presented in lidded 60 -mL soufflé cups with 3 -digit codes, and each sample was evaluated in duplicate by each panelist in separate sessions. Milks were presented to each panelist in a randomized monadic order with a 3 -min enforced rest between samples. Panelists expectorated milks. Data were collected using Compusense Five (version 5.2, Compusense).

Young Adult Acceptance of Chocolate Milk Sweetened by Lactose Hydrolysis. Chocolate milks with sweetness levels $150 \mathrm{~m} M$ sucrose, $7.5 \mathrm{~g} / 100 \mathrm{~mL}$ hydrolyzed lactose, and $10 \mathrm{~g} / 100 \mathrm{~mL}$ hydrolyzed lactose were evaluated by young adult consumers (19-35 yr). The sucrose and hydrolyzed lactose concentrations were chosen from the results of the previous young adult sweetness reduction acceptance test and by descriptive analysis. Chocolate milks with sucrose and 2 different added lactose concentrations were manufactured by the North Carolina State University Dairy Education Unit, Raleigh, NC. The GL enzyme was added to lactose added chocolate milk at the concentrations of $0.3 \%$ (wt/vol) for $7.5 \mathrm{~g} / 100 \mathrm{~mL}$ treatment and $0.4 \%$ (wt/ vol) for $10 \mathrm{~g} / 100 \mathrm{~mL}$ treatment to ensure $>90 \%$ lactose hydrolysis within $24 \mathrm{~h}$ at $4^{\circ} \mathrm{C}$. Hydrolyzed milk was heat treated with a plate heat exchanger (model T4 RGS-16/2, SPX Flow Technology, Greensboro, NC) at $75^{\circ} \mathrm{C}$ for $16 \mathrm{~s}$ to deactivate the enzyme.

Before the consumer test, pilot plant-manufactured chocolate milk with sweetness levels $150 \mathrm{mM}$ sucrose, $7.5 \mathrm{~g} / 100 \mathrm{~mL}$ hydrolyzed lactose, and $10 \mathrm{~g} / 100 \mathrm{~mL}$ hydrolyzed lactose were evaluated by descriptive analysis. Young adult consumers were recruited as previously described with the target number of consumers being 100 . Sample presentations and questionnaire for consumers were the same as described in the previous section of young adult acceptance testing. All participants were compensated with a $\$ 10$ grocery gift card to a local shopping store. Compusense Five (version 5.2, Compusense) was used for data collection.

\section{Statistical Analysis}

Data analysis of power functions was performed using linear regression in XLSTAT version 2012.6.04 (Addinsoft, New York, NY). Analysis of variance was performed on young adult consumer liking data and hydrolysis percentage data using a generalized linear mixed model (PROC GLIMMIX) in SAS software (version 9.2, SAS Institute, Cary, NC). Analysis of variance with means separation (Fisher's least significant difference) was performed on the liking data from children's test results and lactose hydrolyzed chocolate milk consumer test results (XLSTAT). Just-about-right scores were evaluated using chi-squared tests; statistical significance (superscript letters) for purchase intent (5-point scale) was obtained from Kruskal-Wallis nonparametric test; demographic questions were analyzed for frequency of choice (XLSTAT). All statistical analysis was performed at the $95 \%$ confidence interval.

\section{RESULTS AND DISCUSSION}

\section{Experiment 1: Sugar Reduction in Skim Chocolate Milk}

Thresholds and Power Functions of Sweetness in Different Media. The best-estimate detection threshold of sucrose in water was $7.77 \mathrm{~m} M$. For skim milk, whole milk, and skim chocolate milk, the detection thresholds were 8.56, 11.39, and $7.81 \mathrm{mM}$, respectively. For the recognition threshold, sucrose in water was $12.87 \mathrm{mM}$, and for skim milk, whole milk, and skim chocolate milk, the threshold was $13.78,15.63,17.14$ $\mathrm{m} M$, respectively. Recognition thresholds established the starting points of sucrose concentrations for power functions in different matrices, to ensure that the sweetness intensity curve fell within the linear proportion of the power functions. The exponent for water (1.37) was higher than that of skim milk (1.22) and skim chocolate milk (1.12) $(P<0.05$; Figure 1$)$ and is consistent with Fujimaru et al. (2012). Lower power functions in milk compared with water make sense because milk, especially chocolate milk, is more complex than water. Similar results were observed for salty taste in dairy matrices by Drake et al. (2011), where cheese sauce had a lower exponent than soup and water. Iso-sweetness of a well-accepted commercial fat-free chocolate milk (17 $\mathrm{g}$ of added sucrose per $240 \mathrm{~mL}$ ) was calculated as 205 $\mathrm{m} M$ sucrose using the power function of sucrose in skim chocolate milk, which provided the benchmark point for consumer tests.

Acceptance by Young Adults of Sweetness Reduction in Chocolate Milk. The sweetness levels for the young adult acceptance test were selected from the results of threshold and power functions where the lowest concentration was $17.14 \mathrm{~m} M$ (recognition threshold of sucrose in skim chocolate milk) and the highest concentration was $205 \mathrm{~m} M$ (benchmark point). The chocolate milk consumers $(\mathrm{n}=146)$ were $49.3 \%$ male and $50.7 \%$ female, 19 to $35 \mathrm{yr}$ of age, and were mostly Caucasian $(65 \%)$ with annual incomes $<\$ 55,000(65 \%)$. Most of the consumers $(>77 \%)$ did not have children. Sweetness liking scores increased with sweetness levels $(P<0.05)$. Sweetness levels of 205 and $142.2 \mathrm{~m} M$ were 


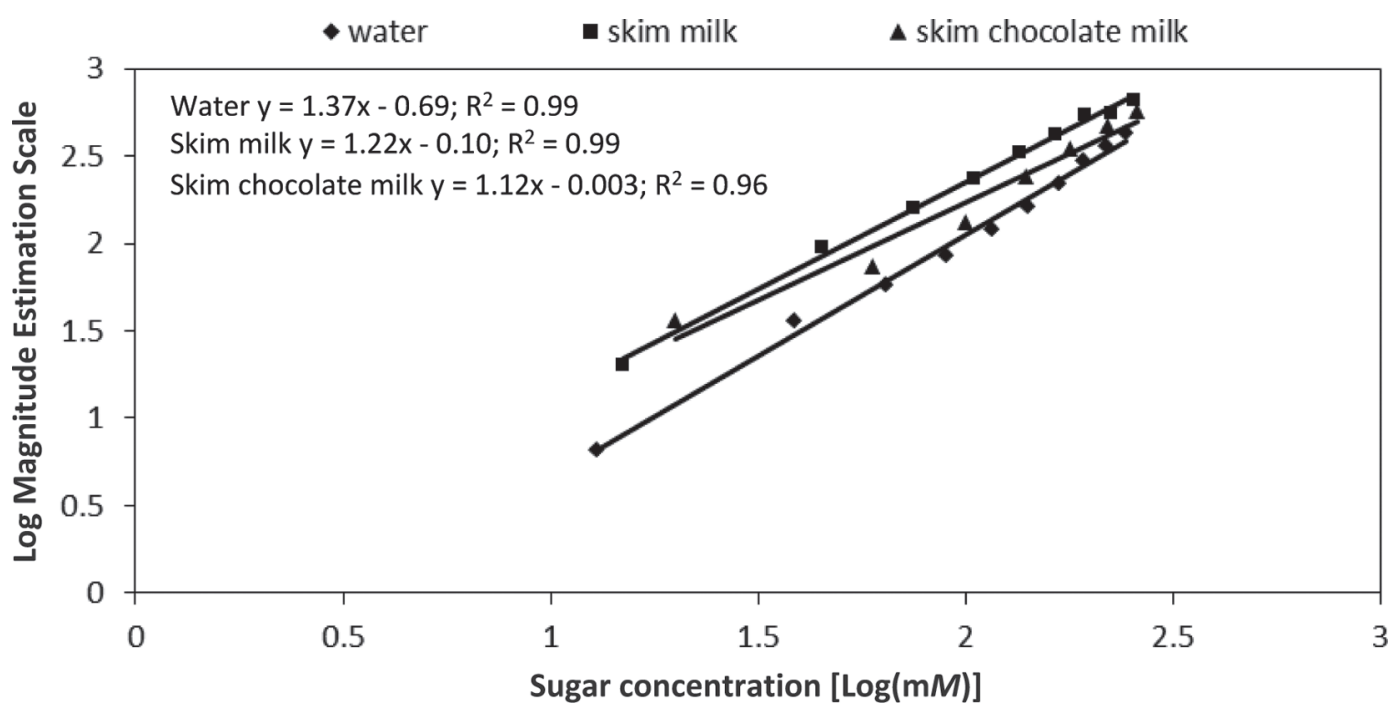

Figure 1. Power functions of sucrose in water, skim milk, and skim chocolate milk.

not significantly different in overall liking, cocoa flavor liking, and thickness liking $(P>0.05)$, and they were both significantly higher compared with other sucrose levels $(P<0.05$; Table 1$)$. Most consumers $(>70 \%)$ evaluated sweetness of 205 and $142.2 \mathrm{~m} M$ as JAR (Table 2). The results suggest that sugar reduction in chocolate milk is possible as long as it does not exceed $30 \%$ reduction (from $205 \mathrm{~m} M$ ).

Sweetness is known to have a hedonic appeal. de Melo et al. (2009) found that sweetness was one of the drivers of liking for reduced-calorie chocolates. Similarly, Bayarri et al. (2011) found that sweetness was one of the drivers of liking for yogurt and yogurt-like products. Recently, Chollet et al. (2013) reported that consumers preferred yogurt with $10 \%$ added sugar, and that $30 \%$ sugar reduction from $10 \%$ added sugar in flavored yogurt was acceptable for consumers but 50\% reduction would be too low. Thompson et al. (2004) reported that cocoa aroma was the driver of liking for chocolate milks in adult consumers, and this finding was subsequently confirmed by Thompson et al.
(2007). However, sugar or sweet taste reduction was not evaluated in these studies. Thompson et al. (2007) also reported that in focus groups, adult participants indicated that the commercial chocolate milks were often too sweet. Similarly, Li et al. (2014) reported that liking of coffee-flavored beverages was penalized by "too much" sweetness, but not as frequently as "too little" sweetness. These studies also suggest that the sugar content of most commercial chocolate milks could be reduced without affecting liking. In the current study, men reported higher liking scores for overall liking, flavor liking, and sweetness liking for chocolate milks, compared with women $(P<0.05)$. This is consistent with Mojet et al. (2005), in which men gave higher liking scores than women for chocolate drinks. Geiselman et al. (1998) reported that the liking of chocolate food for women was based on the perceived sweetness.

Acceptance by Children of Sweetness Reduction in Chocolate Milk. Hedonic scaling can be conducted with children over the age of $4 \mathrm{yr}$ with proper scales, and older children (6-10 yr) can perform discrimina-

Table 1. Young adult liking scores for skim chocolate milk with varying sucrose concentrations ${ }^{1}(\mathrm{n}=146)$

\begin{tabular}{|c|c|c|c|c|c|c|}
\hline \multicolumn{2}{|c|}{ Sucrose concentration } & \multirow{2}{*}{$\begin{array}{l}\text { Overall } \\
\text { liking }\end{array}$} & \multirow{2}{*}{$\begin{array}{c}\text { Overall } \\
\text { flavor liking }\end{array}$} & \multirow{2}{*}{$\begin{array}{l}\text { Sweetness } \\
\text { liking }\end{array}$} & \multirow{2}{*}{$\begin{array}{c}\text { Cocoa } \\
\text { flavor liking }\end{array}$} & \multirow{2}{*}{$\begin{array}{c}\text { Thicknes } \\
\text { liking }\end{array}$} \\
\hline $\mathrm{g} / 240 \mathrm{~mL}$ & $\mathrm{~m} M$ & & & & & \\
\hline 1.4 & 17.14 & $3.2^{\mathrm{e}}$ & $3.1^{\mathrm{f}}$ & $2.7^{\mathrm{e}}$ & $4.0^{\mathrm{e}}$ & $4.8^{\mathrm{d}}$ \\
\hline 2.6 & 32.1 & $3.8^{\mathrm{d}}$ & $3.9^{\mathrm{e}}$ & $3.3^{\mathrm{d}}$ & $4.5^{\mathrm{d}}$ & $5.3^{\mathrm{c}}$ \\
\hline 4.3 & 52.7 & $4.8^{\mathrm{c}}$ & $4.6^{\mathrm{d}}$ & $4.2^{\mathrm{c}}$ & $5.2^{\mathrm{c}}$ & $5.6^{\mathrm{bc}}$ \\
\hline 7.1 & 86.6 & $5.8^{\mathrm{b}}$ & $5.7^{\mathrm{c}}$ & $5.3^{\mathrm{b}}$ & $5.8^{\mathrm{b}}$ & $5.9^{\mathrm{b}}$ \\
\hline 11.7 & 142.2 & $6.8^{\mathrm{a}}$ & $6.8^{\mathrm{b}}$ & $6.6^{\mathrm{a}}$ & $6.7^{\mathrm{a}}$ & $6.5^{\mathrm{a}}$ \\
\hline 16.8 & 205 & $7.2^{\mathrm{a}}$ & $7.2^{\mathrm{a}}$ & $6.9^{\mathrm{a}}$ & $7.0^{\mathrm{a}}$ & $6.8^{\mathrm{a}}$ \\
\hline
\end{tabular}

${ }^{\mathrm{a}-\mathrm{f}}$ Means of each attribute with different superscript letters in columns are significantly different $(P<0.05)$. ${ }^{1}$ Data represent 146 consumers. Liking attributes were scored on a 9-point hedonic scale, where $1=$ dislike extremely and $9=$ like extremely. 
Table 2. Just-about-right scores for skim chocolate milk with varying sucrose concentrations $(\mathrm{n}=146 \text {, young adults })^{1}$

\begin{tabular}{|c|c|c|c|c|c|c|}
\hline Item $^{2}$ & \multicolumn{6}{|c|}{ Sucrose concentration } \\
\hline Not sweet enough & $93.2^{\mathrm{a}}$ & $86.3^{\mathrm{a}}$ & $74.0^{\mathrm{b}}$ & $57.5^{\mathrm{c}}$ & $20.5^{\mathrm{d}}$ & $7.5^{\mathrm{e}}$ \\
\hline Just about right & $5.5^{\mathrm{d}}$ & $11.0^{\mathrm{d}}$ & $24.7^{\mathrm{c}}$ & $39.0^{\mathrm{b}}$ & $71.2^{\mathrm{a}}$ & $74.0^{\mathrm{a}}$ \\
\hline Too sweet & $1.4^{\mathrm{c}}$ & $2.7^{\mathrm{c}}$ & $1.4^{\mathrm{c}}$ & $3.4^{\mathrm{bc}}$ & $8.2^{\mathrm{b}}$ & $18.5^{\mathrm{a}}$ \\
\hline Just about right & $22.6^{\mathrm{e}}$ & $30.1^{\mathrm{d}}$ & $41.8^{\mathrm{c}}$ & $53.1^{\mathrm{b}}$ & $74.0^{\mathrm{a}}$ & $74.0^{\mathrm{a}}$ \\
\hline Too strong & $15.1^{\mathrm{a}}$ & $15.1^{\mathrm{a}}$ & $10.3^{\mathrm{ab}}$ & $4.5^{\mathrm{b}}$ & $4.8^{\mathrm{b}}$ & $6.8^{\mathrm{b}}$ \\
\hline \multicolumn{7}{|l|}{ Thickness JAR (\%) } \\
\hline Not thick enough & $45.9^{\mathrm{a}}$ & $41.1^{\mathrm{ab}}$ & $37.7^{\mathrm{ab}}$ & $30.8^{\mathrm{bc}}$ & $24.0^{\mathrm{c}}$ & $21.9^{\mathrm{c}}$ \\
\hline Just about right & $52.7^{\mathrm{d}}$ & $57.5^{\mathrm{cd}}$ & $61.0^{\mathrm{bcd}}$ & $64.0^{\mathrm{abc}}$ & $69.9^{\mathrm{ab}}$ & $73.3^{\mathrm{a}}$ \\
\hline Too thick & $1.4^{\mathrm{b}}$ & $1.4^{\mathrm{b}}$ & $1.4^{\mathrm{b}}$ & $5.1^{\mathrm{ab}}$ & $6.2^{\mathrm{a}}$ & $4.8^{\mathrm{ab}}$ \\
\hline
\end{tabular}

\footnotetext{
${ }^{a}$ Means of each attribute with different superscript letters in rows are significantly different $(P<0.05)$.

${ }^{1}$ Data represent 146 consumers.

${ }^{2}$ Just-about-right (JAR) scales were scored on a 5 -point scale, where 1 or $2=$ too little, $3=$ just about right, and 4 or $5=$ too much. The percentage of consumers that selected these options is presented.
}

tion tasks (Guinard, 2000). In the current study, for children 5 to 7 yr $(\mathrm{n}=49)$, a higher percentage $(55.1 \%)$ of children preferred the highest sugar concentration $(205 \mathrm{mM})$ over the other 2 concentrations: $140.6 \mathrm{mM}$ $(30.6 \%)$ and $86.6 \mathrm{~m} M(14.3 \% ; P<0.05$; results not shown). However, we detected no significant difference in overall liking scores between 205 and $140.6 \mathrm{mM}$ sucrose (6.3 and 6.1 on a 7 -point scale; $P>0.05$ ), which were both significantly higher than $86.6 \mathrm{~m} M$ (5.2 on a 7 -point scale; $P<0.05)$. Similar results were observed for children ages 8 to $10 \mathrm{yr}$ (Table 3 ). A higher percentage $(41.2 \%)$ of children preferred chocolate milk with $205 \mathrm{~m} M$ sucrose over the other 2 concentrations $(P<$ $0.05)$. However, we observed no significant difference in overall liking scores for 205, 162, and $140.6 \mathrm{mM}(P>$ 0.05 ), but $205 \mathrm{~m} M$ received significantly higher scores in sweetness liking and chocolate flavor liking compared with $140.6 \mathrm{~m} M(P<0.05$; Table 3$)$.

The liking scores of all attributes showed a linear decrease with the decrease of sucrose concentrations below $140.6 \mathrm{mM}(P<0.05)$. For 11 - to 13 -yr-olds, differences for overall liking, sweetness liking, and chocolate liking were observed between 205 and $162 \mathrm{~m} M$ sucrose (Table 4). A higher percentage ( $81.1 \%$ ) of children perceived the chocolate milk as just about right in sweetness for $205 \mathrm{~m} M$ sucrose compared with $140.6 \mathrm{~m} M$ sucrose $(64.2 \% ; P<0.05)$. However, we detected no difference in the percentages of children who thought the chocolate flavor was just about right for both concentrations $(P>0.05)$. A higher percentage $(41.5 \%)$ of children preferred $205 \mathrm{mM}$ over other sucrose concentrations $(P$ $<0.05)$. The results of the current study showed that a clearer differentiation in liking scores with different sugar concentrations was observed with increasing age. Older children had more distinct preferences compared with younger children. It is also possible that the older children have better performance with lower noise because they can more effectively utilize the scale, which results in greater differences.

Guinard (2000) reported that children begin to develop reliable differentiation in the pleasantness of odors at the age of $5 \mathrm{yr}$, and another study showed that 6 - to

Table 3. Acceptance scores for skim chocolate milk with varying sucrose concentrations $(8-10 \mathrm{yr} ; \mathrm{n}=51)^{1}$

\begin{tabular}{|c|c|c|c|c|c|}
\hline \multirow[b]{2}{*}{ Item $^{2}$} & \multicolumn{5}{|c|}{ Sucrose concentration } \\
\hline & $\begin{array}{c}205 \mathrm{~m} M \\
(16.8 \mathrm{~g} / 240 \mathrm{~mL})\end{array}$ & $\begin{array}{c}162 \mathrm{mM} \\
(13.3 \mathrm{~g} / 240 \mathrm{~mL})\end{array}$ & $\begin{array}{c}140.6 \mathrm{mM} \\
(11.5 \mathrm{~g} / 240 \mathrm{~mL})\end{array}$ & $\begin{array}{c}126 \mathrm{mM} \\
(10.3 \mathrm{~g} / 240 \mathrm{~mL})\end{array}$ & $\begin{array}{c}86.6 \mathrm{mM} \\
(7.1 \mathrm{~g} / 240 \mathrm{~mL})\end{array}$ \\
\hline Sweetness liking & $5.7^{\mathrm{a}}$ & $5.6^{\mathrm{ab}}$ & $5.1^{\mathrm{bc}}$ & $4.7^{\mathrm{c}}$ & $3.7^{\mathrm{d}}$ \\
\hline Chocolate taste liking & $6.1^{\mathrm{a}}$ & $6.0^{\mathrm{ab}}$ & $5.5^{\mathrm{bc}}$ & $5.1^{\mathrm{c}}$ & $4.1^{\mathrm{d}}$ \\
\hline Overall preference $^{3}(\%)$ & $41.2^{\mathrm{a}}$ & $13.7^{\mathrm{b}}$ & $15.7^{\mathrm{b}}$ & $17.6^{\mathrm{b}}$ & $11.8^{\mathrm{b}}$ \\
\hline
\end{tabular}

\footnotetext{
${ }^{\mathrm{a}-\mathrm{d}}$ Means of each attribute with different superscript letters in rows are significantly different $(P<0.05)$.

${ }^{1}$ Data represent 51 consumers.

${ }^{2}$ Liking attributes were scored on a 7 -point hedonic "smiley face" scale, where $1=$ super bad and $7=$ super good.

${ }^{3}$ Percentage of participants who preferred the sample.
} 
Table 4. Acceptance scores for skim chocolate milk with varying sucrose concentrations ${ }^{1}(11-13$ yr; $\mathrm{n}=53)$

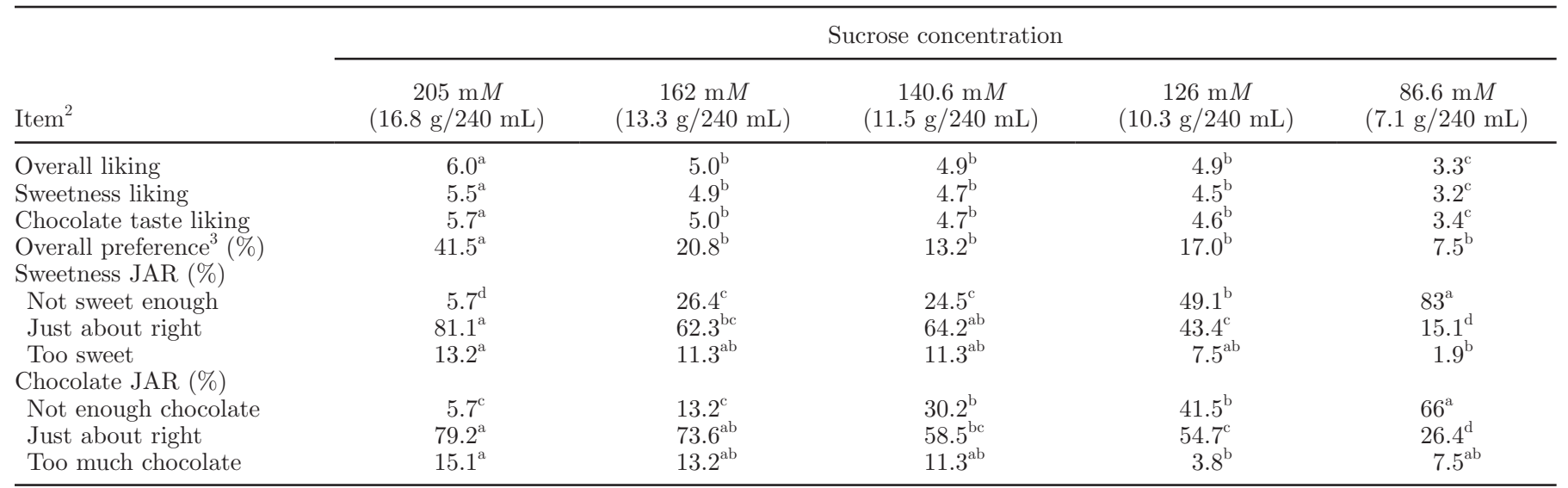

\footnotetext{
${ }^{\mathrm{a}-\mathrm{d}}$ Means of each attribute with different superscript letters in rows are significantly different $(P<0.05)$.

${ }^{1}$ Data represent 53 consumers.

${ }^{2}$ Liking attributes were scored on a 7 -point hedonic "smiley face" scale, where $1=$ super bad and $7=$ super good. Just-about-right (JAR) scales were scored on a 3 -point scale with smiley faces, where $1=$ too little, $2=$ just about right, and $3=$ too much.

${ }^{3}$ Percentage of participants who preferred the sample.
}

12-yr-old children can scale the perceived intensity of sweet in orange-flavored beverages (Zandstra and de Graaf, 1998). Early studies of Desor et al. (1975) found that, compared with adults, children preferred higher concentrations of sucrose and lactose. However, in an ethnic group study, Thompson et al. (2007) reported that Hispanic children were less discerning than adults (Hispanic or Caucasian) in their preferences for chocolate milk sweetness and chocolate flavor. The chocolate milks in that study were all commercial products and had no sugar reduction (Thompson et al., 2007). In the current study, 11- to 13-yr-old children were more discerning on the sweetness of chocolate milk than were young adults. Young adults did not show differences on overall liking and sweetness liking between chocolate milks with 205 and $142.2 \mathrm{~m} M$ sucrose $(P>0.05)$, whereas 11- to 13-yr-old children showed differences between chocolate milks with 205 and $162 \mathrm{mM}$ sucrose $(P<0.05)$. Monneuse et al. (1991) reported that boys preferred higher sweetness than girls, but in the current study, differences between boys and girls were not observed within each age category for children $(P>$ 0.05). However, differences between male and female young adults were observed in the current study $(P<$ 0.05), as previously described.

Because skim chocolate milk with $140.6 \mathrm{~m} M$ sucrose received an overall liking score of 4.9 on a 7 -point scale for 11- to 13-yr-old children, where 5 equals good, and the overall liking score of $140.6 \mathrm{mM}$ was not significantly different from that for skim chocolate milk with $205 \mathrm{~m} M$ sucrose for 5- to 10-yr-old children, we propose that the sucrose concentration in chocolate milk for both young adults and children can be reduced to between 140.6 and $162 \mathrm{mM}$, which represents a 21 to $31 \%$ sugar reduction. Combined with young adult acceptance scores, $150 \mathrm{mM}$ sucrose concentration in chocolate milk was chosen as the lowest acceptable sweetness level for subsequent experiments.

\section{Experiment 2: Alternative Sweetening by Lactose Hydrolysis}

Lactose Hydrolysis. Variability of lactose hydrolysis percentages $(75-96 \%, 24 \mathrm{~h})$ was observed among different milks (raw whole, pasteurized whole, and pasteurized skim), where LL resulted in the lowest percentage $(75-84 \%)$ of hydrolysis compared with other enzymes ( $>95 \% ; P<0.05)$; no difference was detected among the other 3 enzymes for milks $(P>0.05)$. We also found no difference among different milks for each enzyme $(P>0.05$; results not shown). Horner et al. (2011) also observed differences in lactose hydrolysis percentages among enzymes in refrigerated milks, and the hydrolysis was not affected by fat content or processing of milk. For spray-dried permeate, overall $0.2 \%$ (wt/vol) had higher percentages of hydrolysis for $10 \%$ (wt/wt) solutions compared with $0.1 \%$ (wt/vol) at both the 12 - and 24 -h time points $(P<0.05)$. Similar to milks, LL had the lowest percentages of hydrolysis for all permeates compared with the other 3 enzymes $(P<0.05)$. Variability was also observed among permeates from different suppliers (3.9-95\%). However, total nitrogen and selected mineral analysis of potassium, calcium, magnesium, sodium, and chloride for all 5 permeates were not different $(P>0.05)$, which suggests that the differences in hydrolysis were due to other 
component differences (Frankowski et al., 2014) or to differences in other minerals such as zinc, phosphate, or manganese (Kim et al., 1997; results not shown). Fresh liquid permeate had similar results to milks, where LL resulted in the lowest hydrolysis $(>86 \%)$ compared with the other 3 enzymes ( $>96 \% ; P<0.05)$. Overall, 1 spray-dried permeate, 1 lactose, and the GL and HL enzymes were selected from lactose hydrolysis results because of consistent hydrolysis after $24 \mathrm{~h}$ at $4^{\circ} \mathrm{C}$.

Descriptive Analysis of Hydrolyzed Chocolate Milk. Lactose hydrolysis by selected enzymes in chocolate milk with added lactose $(0,2,5,7.5$, or $10 \mathrm{~g} / 100$ $\mathrm{mL})$ and added spray-dried powdered permeate $(0,2$, $5,7.5$, or $10 \mathrm{~g}$ of lactose content $/ 100 \mathrm{~mL}$ ) treatments were all $>90 \%$. Differences were not observed between GL and HL enzymes $(P>0.05$; results not shown). Without added sugar, hydrolyzed skim chocolate milk had a sweetness score of 1.8 on an intensity scale from 0 to 15 compared with "not detected" (0) for chocolate milk with no hydrolyzed lactose (Figure 2). Lactose-free milk was confirmed to have higher sweet taste (Adhikari et al., 2010) compared with regular commercial milk. Hydrolyzed skim chocolate milk with $10 \mathrm{~g}$ of added lactose/100 mL matched the sweetness level of the benchmark chocolate milk (205 $\mathrm{m} M$ sucrose), and hydrolyzed skim chocolate milk with $7.5 \mathrm{~g}$ of added lactose/100 mL matched the sweetness level of the consumer-acceptable sucrose-reduced chocolate milk $(150 \mathrm{~m} M$ sucrose; $P>$ 0.05; Figure 2). For permeate treatments (Figures 3 and 4), hydrolyzed skim chocolate milk with permeate addition that contained $10 \mathrm{~g}$ of lactose matched the lowest acceptable sweetness of chocolate milk (150 $\mathrm{mM}$ sucrose; $P>0.05$ ); however, the salty taste was obvious (7.6/15 intensity scale). As such, we determined that hydrolyzed chocolate milk with permeate addition was not suitable for a consumer test. Frankowski et al. (2014) reported that ingredients other than sodium, especially potassium and organic acids, in permeate contribute to salty taste. We detected no differences in aroma, cooked milk, or chocolate flavor of milks $(P$ $>0.05)$. Bitterness was not detected in hydrolyzed chocolate milks with added lactose above $7.5 \mathrm{~g} / 100 \mathrm{~mL}$ and added permeate with above $2 \mathrm{~g}$ of lactose content/100 mL. Studies have found that bitterness can be suppressed by salts (Keast et al., 2001; Leksrisompong et al., 2012), which explains why a higher content of lactose had to be added to milk compared with permeate added to milk to mask the bitterness of chocolate milk. The salty taste components of permeate may have contributed to reduced perception of bitter taste.

Young Adult Acceptance of Chocolate Milk Sweetened by Lactose Hydrolysis. Pilot plantmanufactured chocolate milk with $7.5 \mathrm{~g} / 100 \mathrm{~mL}$ hydrolyzed lactose was lower in sweet taste than that of the $150 \mathrm{mM}$ sucrose treatment, and the $10 \mathrm{~g} / 100 \mathrm{~mL}$ lactose treatment was higher by descriptive analysis $(P<0.05)$. We detected no significant difference in other sensory attributes. One hundred three consumers

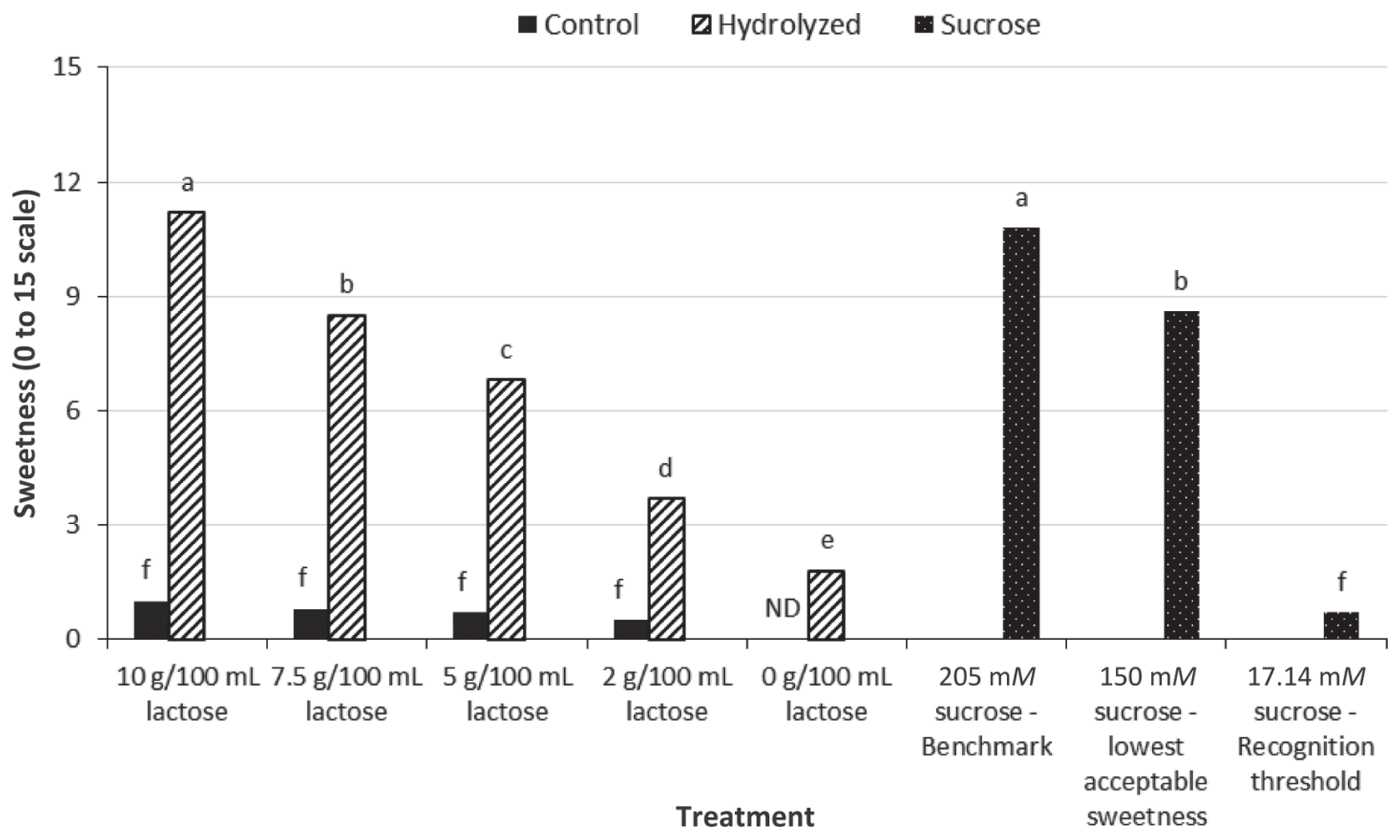

Figure 2. Trained panel sweet taste scores of skim chocolate milk with sucrose and lactose hydrolyzed skim chocolate milk with different levels of lactose addition $\left(4^{\circ} \mathrm{C}\right.$ for $\left.24 \mathrm{~h}\right)$. Control $=$ without hydrolysis; hydrolyzed $=$ lactose hydrolyzed; ND $=$ not detected. Different letters above bars signify significant differences $(P<0.05)$. 


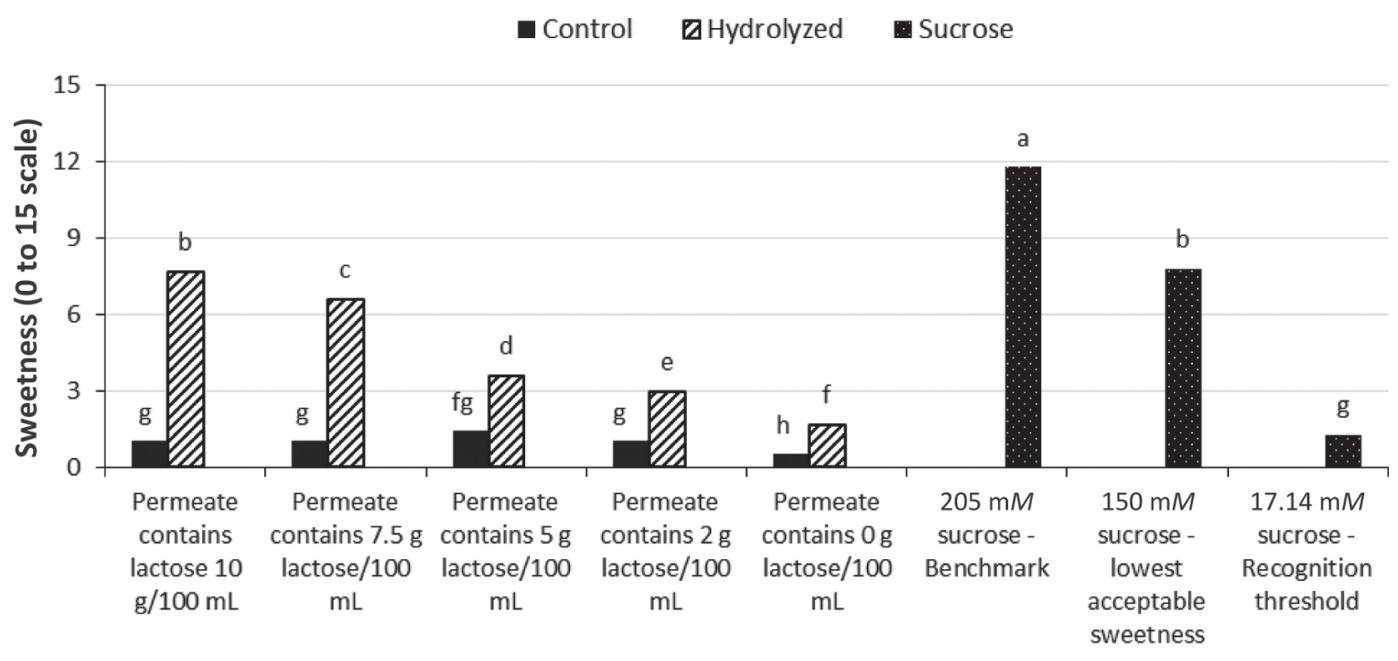

Treatment

Figure 3. Trained panel sweet taste scores of skim chocolate milk with sucrose and lactose hydrolyzed skim chocolate milk with different levels of permeate addition $\left(4^{\circ} \mathrm{C}\right.$ for $\left.24 \mathrm{~h}\right)$. Control = without hydrolysis; hydrolyzed = lactose hydrolyzed. Different letters above bars signify significant differences $(P<0.05)$.

participated in the consumer acceptance test $(41.7 \%$ male and $58.3 \%$ female, 19-35 yr). The consumers were mostly Caucasian (58\%) with annual incomes $<\$ 55,000$ $(79 \%)$. Most consumers (>80\%) did not have children. We detected no difference in appearance, overall liking, flavor, sweetness, cocoa flavor, thickness liking, or purchase intent between $10 \mathrm{~g} / 100 \mathrm{~mL}$ hydrolyzed lactose milk and $150 \mathrm{mM}$ sucrose milk (Table 5). The results are consistent with the previous young adult sweetness reduction acceptance test, which established that there was no difference in overall liking between benchmark sweetness level (205 $\mathrm{mM}$ sucrose) and the lowest acceptable sweetness level (150 $\mathrm{m} M$ sucrose). Adhikari et al. (2010) found that other than higher sweetness intensity, ultrapasteurized lactose-free milk also has higher intensities of cooked and processed flavors compared with regular milk, and chalkiness is also present. Other flavor differences were not observed in the current study, perhaps because of the differences between plain milk and chocolate milk or due to processing and differences in age or storage among the commercial milks that were used in the previous study. The

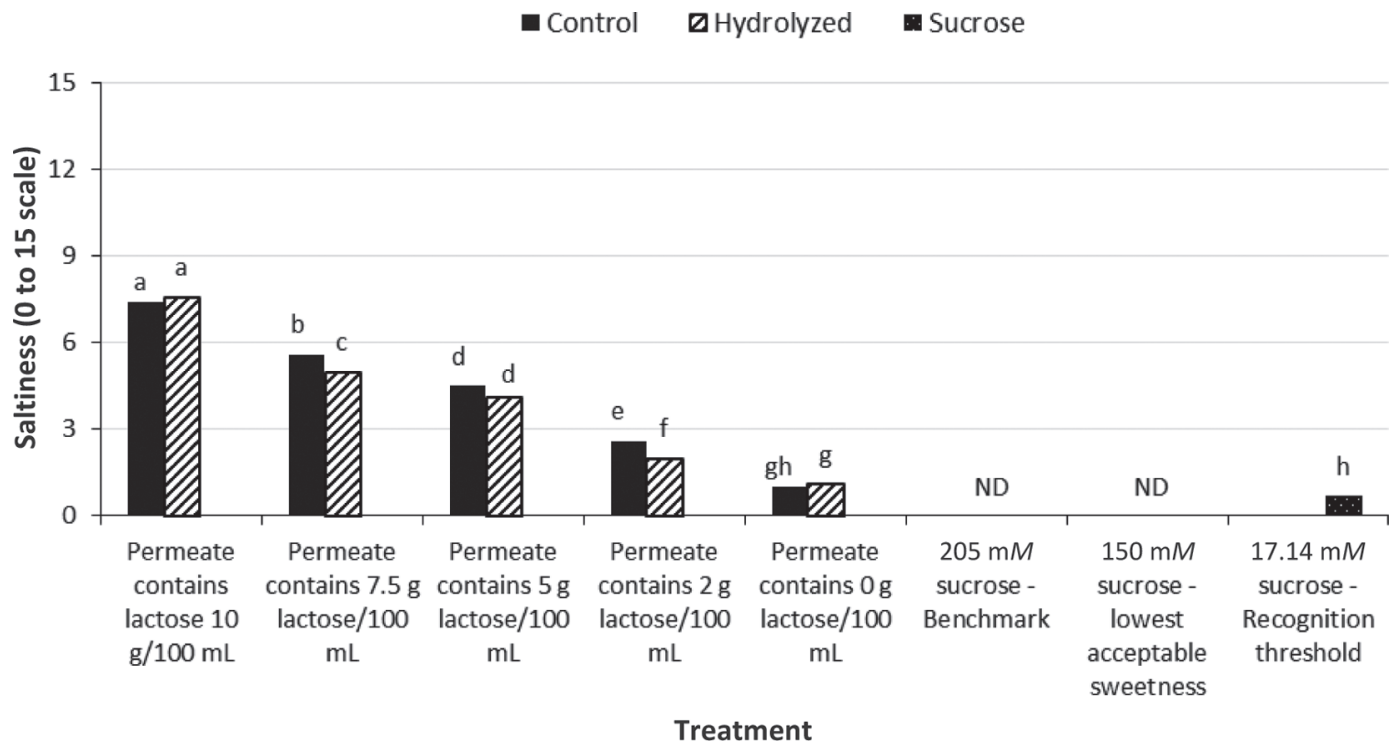

Figure 4. Trained panel salty taste scores of skim chocolate milk with sucrose and lactose hydrolyzed skim chocolate milk with different levels of permeate addition $\left(4^{\circ} \mathrm{C}\right.$ for $\left.24 \mathrm{~h}\right)$. Control $=$ without hydrolysis; hydrolyzed $=$ lactose hydrolyzed; ND $=$ not detected. Different letters above bars signify significant differences $(P<0.05)$. 
Table 5. Young adult acceptance scores for lactose hydrolyzed chocolate milks ${ }^{1}$ ( $\left.\mathrm{n}=103\right)$

\begin{tabular}{|c|c|c|c|}
\hline Item $^{2}$ & $\begin{array}{c}\text { Sucrose } \\
(150 \mathrm{~m} M)\end{array}$ & $\begin{array}{l}\text { Lactose high } \\
(10 \mathrm{~g} / 100 \mathrm{~mL})\end{array}$ & $\begin{array}{c}\text { Lactose low }{ }^{3} \\
(7.5 \mathrm{~g} / 100 \mathrm{~mL})\end{array}$ \\
\hline Appearance liking & $6.7^{\mathrm{a}}$ & $6.2^{\mathrm{ab}}$ & $6.1^{\mathrm{b}}$ \\
\hline Overall liking & $6.8^{\mathrm{a}}$ & $6.6^{\mathrm{a}}$ & $6.0^{\mathrm{b}}$ \\
\hline Flavor liking & $6.8^{\mathrm{a}}$ & $6.7^{\mathrm{a}}$ & $5.9^{\mathrm{b}}$ \\
\hline Sweetness liking & $6.5^{\mathrm{a}}$ & $6.5^{\mathrm{a}}$ & $6.0^{\mathrm{b}}$ \\
\hline \multicolumn{4}{|l|}{ Sweetness JAR (\%) } \\
\hline Not sweet enough & $24.3^{\mathrm{b}}$ & $16.5^{\mathrm{b}}$ & $39.8^{\mathrm{a}}$ \\
\hline Just about right & $58.3^{\mathrm{a}}$ & $64.1^{\mathrm{a}}$ & $56.3^{\mathrm{a}}$ \\
\hline Too sweet & $17.5^{\mathrm{a}}$ & $19.4^{\mathrm{a}}$ & $3.9^{\mathrm{b}}$ \\
\hline Cocoa flavor liking & $6.9^{\mathrm{a}}$ & $6.6^{\mathrm{a}}$ & $5.9^{\mathrm{b}}$ \\
\hline \multicolumn{4}{|c|}{ Cocoa flavor JAR (\%) } \\
\hline Too mild & $23.3^{\mathrm{c}}$ & $35.9^{\mathrm{b}}$ & $49.5^{\mathrm{a}}$ \\
\hline Just about right & $70.9^{\mathrm{a}}$ & $60.2^{\mathrm{ab}}$ & $46.6^{\mathrm{b}}$ \\
\hline Too strong & $5.8^{\mathrm{a}}$ & $3.9^{\mathrm{a}}$ & $3.9^{\mathrm{a}}$ \\
\hline Thickness liking & $6.4^{\mathrm{a}}$ & $6.1^{\mathrm{a}}$ & $5.2^{\mathrm{b}}$ \\
\hline \multicolumn{4}{|l|}{ Thickness JAR (\%) } \\
\hline Too thin & $32.0^{\mathrm{b}}$ & $40.8^{\mathrm{ab}}$ & $54.4^{\mathrm{a}}$ \\
\hline Just about right & $63.1^{\mathrm{a}}$ & $58.3^{\mathrm{a}}$ & $41.7^{\mathrm{b}}$ \\
\hline Too thick & $4.9^{\mathrm{a}}$ & $1.0^{\mathrm{a}}$ & $3.9^{\mathrm{a}}$ \\
\hline Purchase intent & $3.5^{\mathrm{a}}$ & $3.4^{\mathrm{a}}$ & $2.9^{\mathrm{b}}$ \\
\hline Preference $^{4}$ & $40.8^{\mathrm{a}}$ & $43.7^{\mathrm{a}}$ & $15.5^{\mathrm{b}}$ \\
\hline
\end{tabular}

${ }^{\mathrm{a}-\mathrm{c}}$ Means of each attribute with different superscript letters in rows are significantly different $(P<0.05)$.

${ }^{1}$ Data represent 103 consumers.

${ }^{2}$ Liking attributes were scored on a 9-point hedonic scale, where dislike extremely $=1$ and like extremely $=9$. Just-about-right (JAR) scales were scored on a 5 -point scale, where too little $=1$ or 2 , just about right $=3$, and too much $=4$ or 5 . Percentage of consumers that selected these options is presented. Purchase intent was scored on a 5 -point scale, where would not buy $=1$ or 2 , may or may not $=3$, and would buy $=4$ or 5 ; for purchase intent, statistical letterings were obtained from Kruskal-Wallis nonparametric test.

${ }^{3}$ Lactose high is hydrolyzed lactose milk (GODO-YNL2 Yeast Neutral Lactase, $24 \mathrm{~h}$ at $4{ }^{\circ} \mathrm{C}$; Danisco A/S, Copenhagen, Denmark) with $10 \mathrm{~g} / 100 \mathrm{~mL}$ added lactose; lactose low is hydrolyzed lactose milk (GODO-YNL2 Yeast Neutral Lactase, $24 \mathrm{~h}$ at $4^{\circ} \mathrm{C}$ ) with $7.5 \mathrm{~g} / 100 \mathrm{~mL}$ added lactose.

${ }^{4}$ Percentage of participants who preferred the sample.

amount of lactose required to achieve the same level of sweetness ( $>72$ added $\mathrm{kcal} / 240 \mathrm{~mL}$ ) compared with regular sucrose sweetened chocolate milk $(67.2$ added $\mathrm{kcal} / 240 \mathrm{~mL}$ ) was too high to fulfill a calorie-reduced requirement. This is possibly because of the complexity of chocolate milk and the requirement to overpower the bitterness of cocoa. The viability of lactose hydrolysis as the sole sweetening source may be a possibility for other flavored milks such as vanilla that have no inherent bitter taste, and a lower level of sweetener and sweet taste may be acceptable. Future studies should address this application.

\section{CONCLUSIONS}

This study established the perception of sweetness intensity of sucrose in different dairy matrices and determined that sucrose reduction in chocolate milk for both children and young adults is possible as long as it does not exceed 30\% reduction (from $205 \mathrm{mM}$ ). Sweetness of sucrose can be achieved by lactose hydrolysis of added lactose, and it is possible to use lactose hydrolysis of added lactose but not added permeate to sweeten chocolate milk. However, the additional calories from added lactose indicate that this approach might be more suitable for other flavored milks with simpler characteristics, where the amount of added lactose can be reduced. Future studies should address the viability of lactose hydrolysis as a sweetening approach for other dairy beverages and investigate other alternative sweeteners.

\section{ACKNOWLEDGMENTS}

Funding was provided in part by the Dairy Research Institute (Rosemont, IL). The use of tradenames does not imply endorsement nor lack of endorsement by those not mentioned.

\section{REFERENCES}

Adhikari, K., L. M. Dooley, E. Chambers IV, and N. Bhumiratana. 2010. Sensory characteristics of commercial lactose-free milks manufactured in the United States. Lebenson. Wiss. Technol. 43:113-118.

Anonymous. 2003. Tools for innovation: Dairy foods for today's preteens. Accessed May 2013. http://www.dairyfoods.com/articles/ tools-for-innovation-dairy-foods-for-today-s-pre-teens.

ASTM International. 1991 ASTM E679-91 (Reapproved 1997): Standard practice for determination of odor and taste thresholds by 
forced-choice ascending concentration series method of limits. Pages 36-40. ASTM International, West Conschohocken, PA.

Bayarri, S., I. Carbonell, E. X. Barrios, and E. Costell. 2011. Impact of sensory differences on consumer acceptability of yoghurt and yoghurt-like products. Int. Dairy J. 21:111-118.

Berkey, C. S., H. R. Rockett, A. E. Field, M. W. Gillman, and G. A. Colditz. 2004. Sugar-added beverages and adolescent weight change. Obes. Res. 12:778-788.

Boor, K. J. 2001. Fluid dairy product quality and safety: Looking to the future. J. Dairy Sci. 84:1-11.

Chollet, M., D. Gille, A. Schmid, B. Walther, and P. Piccinali. 2013. Acceptance of sugar reduction in flavored yogurt. J. Dairy Sci. 96:5501-5511.

de Melo, L. L. M. M., H. M. A. Bolinia, and P. Efraim. 2009. Sensory profile, acceptability, and their relationship for diabetic/reduced calorie chocolates. Food Qual. Prefer. 20:138-143.

Desor, J. A., L. J. Greene, and O. Maller. 1975. Preferences for sweet and salty in 9-15 year old and adult humans. Science 190:686687

Drake, M. A., and G. V. Civille. 2003. Flavor lexicons. Compr. Rev. Food Sci. Food Safety 2:33-40.

Drake, S. L., K. Lopetcharat, and M. A. Drake. 2011. Salty taste in dairy foods: Can we reduce the salt? J. Dairy Sci. 94:636-645.

Frankowski, K. M., R. E. Miracle, and M. Drake. 2014. The role of sodium in salty taste of permeate. J. Dairy Sci. 97:5356-5370.

Fujimaru, T., J. H. Park, and J. Lim. 2012. Sensory characteristics and relative sweetness of tagatose and other sweeteners. J. Food Sci. 77:S323-S328.

Geiselman, P. J., C. F. Smith, D. A. Williamson, C. M. Champagne, G. A. Bray, and D. H. Ryan. 1998. Perception of sweetness intensity determines women's hedonic and other perceptual responsiveness to chocolate food. Appetite 31:37-48.

Guinard, J. X. 2000. Sensory and consumer testing with children. Food Sci. Technol. (Campinas.) 11:273-283.

Hoag, C. 2011. Flavored milk banned in LA schools. Accessed July 2013. http://www.huffingtonpost.com/2011/06/15/la-schools flavored-milk_n_877282.html?view=print\&comm_ref=false.

Horner, T. W., M. L. Dunn, D. L. Eggett, and L. V. Ogden. 2011. $\beta$-galactosidase activity of commercial lactase samples in raw and pasteurized milk at refrigerated temperatures. J. Dairy Sci. 94:3242-3249.

International Dairy Foods Association. 2012. Dairy Facts. 2012 Edition. International Dairy Foods Association, Washington, DC.

Keast, R. S. J., P. A. S. Breslin, and G. K. Beauchamp. 2001. Suppression of bitterness using sodium salts. Chimia (Aarau) 55:441-447.

Kim, M. K., K. Lopetcharat, and M. A. Drake. 2013. Influence of packaging information on consumer liking of chocolate milk. J. Dairy Sci. 96:4843-4856.

Kim, S. H., K. P. Lim, and H. S. Kim. 1997. Differences in the hydrolysis of lactose and other substrates by $\beta$-D-Galactosidase from Kluyveromyces lactis. J. Dairy Sci. 80:2264-2269.

Kroll, B. J. 1990. Evaluating rating scales for sensory testing with children. Food Technol. 44:78-80, 82, 84, and 86.

Lawless, H. T. C. Hartono, and S. Hernandez. 2000. Threshold and suprathreshold intensity functions for capsaisin in oil and aqueousbased carriers. J. Sens. Stud. 15:437-477.

Leksrisompong, P., D. M. Barbano, A. Foegeding, P. Gerard, and M. A. Drake. 2010. The roles of fat and $\mathrm{pH}$ on the detection thresholds and partition coefficients of three compounds: Diacetyl, $\delta$-decalactone and furaneol. J. Sens. Stud. 25:347-370.
Leksrisompong, P., P. Gerard, K. Lopetcharat, and M. Drake. 2012 Bitter taste inhibiting agents for whey protein hydrolysate and whey protein hydrolysate beverages. J. Food Sci. 77:S282-S287.

Li, B., J. E. Hayes, and G. R. Ziegler. 2014. Just-about-right and ideal scaling provide similar insights into the influence of sensory attributes on liking. Food Qual. Prefer. 37:71-78.

Li, X. E., R. E. Campbell, A. J. Fox, P. D. Gerard, and M. A. Drake. 2012. Influence of storage, heat treatment, and solids composition on the bleaching of whey with hydrogen peroxide. J. Food Sci. 77:C798-C804.

Malik, V. S., M. B. Schulze, and F. B. Hu. 2006. Intake of sugarsweetened beverages and weight gain: A systematic review. Am. J. Clin. Nutr. 84:274-288.

Meilgaard, M. M., G. V. Civille, and B. T. Carr. 1999. Selection and training of panel members. Pages 135-183 in Sensory Evaluation Techniques. 2nd ed. CRC Press, Boca Raton, FL.

Mojet, J., E. Christ-Hazelhof, and J. Heidema. 2005. Taste perception with age: Pleasantness and its relationships with threshold sensitivity and supra-threshold intensity of five taste qualities. Food Qual. Prefer. 16:413-423.

Monneuse, M. O., F. Bellisle, and J. Louis-Sylvestre. 1991. Impact of sex and age on sensory evaluation of sugar and fat in dairy products. Physiol. Behav. 50:1111-1117.

Murphy, M. M., J. S. Douglass, R. K. Johnson, and L. A. Spence. 2008. Drinking flavored or plain milk is positively associated with nutrient intake and is not associated with adverse effects on weight status in US children and adolescents. J. Am. Diet. Assoc. 108:631-639.

NDC (National Dairy Council). 2010. Top five reasons to raise your hand for flavored milk. Accessed March 2014. http://efnep.ucanr. edu/files/98997.pdf.

Plotto, A., C. A. Margaría, K. L. Goodner, R. Goodrich, and E. A. Baldwin. 2004. Odor and flavor thresholds for key aroma components in an orange juice matrix: terpenes and aldehydes. Flavour Fragrance J. 19:491-498.

Popper, R., and J. J. Kroll. 2005. Conducting sensory research with children. J. Sens. Stud. 20:75-87.

Quann, E. E., and D. Adams. 2013. Impact on milk consumption and nutrient intakes from eliminating flavored milk in elementary schools. Nutr. Today 48:127-134.

Schiffman, S. S., B. J. Booth, M. L. Losee, S. D. Pecore, and Z. S. Warwick. 1995. Bitterness of sweeteners as a function of concentration. Brain Res. Bull. 36:505-513.

Thompson, J. L., M. A. Drake, K. Lopetcharat, and M. D. Yates. 2004. Preference mapping of commercial chocolate milks. J. Food Sci. 69:406-413.

Thompson, J. L., P. D. Gerard, and M. A. Drake. 2007. Chocolate milk and the Hispanic consumer. J. Food Sci. 72:S666-S675.

Upreti, P., L. L. McKay, and L. E. Metzger. 2006. Influence of calcium and phosphorus, lactose, and salt-to-moisture ratio on Cheddar cheese quality: Changes in residual sugars and water-soluble organic acids during ripening. J. Dairy Sci. 89:429-443.

USDA-HHS (USDA-Department of Health and Human Services). 2010. Dietary Guidelines for Americans. 7th ed. USDA-HHS, Washington, DC.

Zandstra, E. H., and C. de Graaf. 1998. Sensory perception and pleasantness of orange beverages from childhood to old age. Food Qual. Prefer. 9:5-12 